\title{
The genetic profiles and maternal origin of local sheep breeds on Java Island (Indonesia) based on complete mitochondrial DNA D-Ioop sequences
}

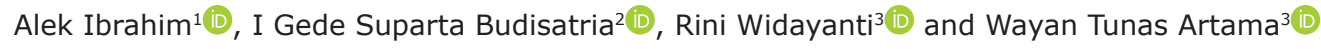

1. Veterinary Science Postgraduate Study Program, Faculty of Veterinary Medicine, Universitas Gadjah Mada, Yogyakarta, Indonesia; 2. Department of Animal Production, Faculty of Animal Science, Universitas Gadjah Mada, Yogyakarta, Indonesia; 3. Department of Biochemistry and Molecular Biology, Faculty of Veterinary Medicine, Universitas Gadjah Mada, Yogyakarta, Indonesia.

Corresponding author: Wayan Tunas Artama, e-mail: artama@ugm.ac.id

Co-authors: AI: alek.ibrahim@mail.ugm.ac.id, IGSB: budisatria@ugm.ac.id, RW: rini_widayanti@ugm.ac.id Received: 30-06-2020, Accepted: 21-10-2020, Published online: 11-12-2020

doi: www.doi.org/10.14202/vetworld.2020.2625-2634 How to cite this article: Ibrahim A, Budisatria IGS, Widayanti R, Artama WT (2020) The genetic profiles and maternal origin of local sheep breeds on Java Island (Indonesia) based on complete mitochondrial DNA D-loop sequences, Veterinary World, 13(12): 2625-2634.

\begin{abstract}
Background and Aim: Java Island is one of the islands in Indonesia which has local sheep breeds with specific characteristics and native development geography in certain regions. This study aimed to determine the genetic profiles and maternal origin of six local sheep breeds on Java Island.

Materials and Methods: This study was conducted by identifying the profiles of complete mitochondrial DNA (mtDNA) displacement loop (D-loop) region sequences on a total of 22 individual in six local sheep breeds on Java Island, including Javanese thin-tailed (JTT), Javanese Fat-Tailed (JFT), Batur (BTR), Wonosobo (WSB), Garut (GRT), and Priangan (PRG) sheep. The D-loop region was amplified using specific primers, and the polymerase chain reaction (PCR) was performed. The PCR products were purified and sequenced.

Results: The mtDNA D-loop analysis identified 21 haplotypes in the analyzed 22 animals with 123 polymorphic sites (V) consisting of 60 singleton variable sites $(\mathrm{S})$ and 63 parsimony informative sites $(\mathrm{P})$. Within all breeds tested, the haplotype diversity, the average number of pairwise differences (K), and nucleotide diversity (Pi) were 0.99567, 25.36364, and 0.02153, respectively. The genetic distance (D) within groups and between groups was 0.001-0.006 and 0.004-0.036, respectively. The phylogeny resulted in the presence of two haplogroups (Hap), which are 5 Hap A and 16 Hap B. All JTT, JFT, BTR, and WSB breeds were in the same cluster in Hap B, whereas GRT and PRG breeds were in clusters in both Hap A and Hap B.

Conclusion: The high genetic diversity in six local sheep breeds on Java Island suggests that they originated from different genetic sources. JTT sheep have closer genetic relationships to JFT, BTR, and WSB sheep, and they are close to European sheep, whereas GRT sheep have closer genetic relationships to PRG sheep. Both are closer to Asian sheep than to European sheep.
\end{abstract}

Keywords: control region, genetic variation, indigenous sheep, Indonesian sheep, non-coding region, phylogenetic.

\section{Introduction}

Indonesia is an archipelago country that has specific characteristics in each Island and a variety of natural and human resources. Java Island is one of the islands in Indonesia, which consists of four provinces (Banten, West Java, Central Java, and East Java) and two special regions (Jakarta and Yogyakarta). In general, these regions have similar characteristics, but in certain regions, they have unique characteristics regarding geographic features, natural resources, social, and cultural background. The character of the region and different natural resources dictate the type a socio-cultural community that will be established, at

Copyright: Ibrahim, et al. Open Access. This article is distributed under the terms of the Creative Commons Attribution 4.0 International License (http://creativecommons.org/licenses/ by/4.0/), which permits unrestricted use, distribution, and reproduction in any medium, provided you give appropriate credit to the original author(s) and the source, provide a link to the Creative Commons license, and indicate if changes were made. The Creative Commons Public Domain Dedication waiver (http:// creativecommons.org/publicdomain/zero/1.0/) applies to the data made available in this article, unless otherwise stated. least with respect to farming activities. Farming activities adjust to the conditions of the area, including the selection of livestock that is suitable for rising. Sheep are one of the many livestock raised by farmers on Java Island that have a notable value in society $[1,2]$. Sheep play key roles in providing food, clothing, the raw material for traditional housing [3], agriculture, economy [4,5], religious festivities, and cultural/traditional festivals [6-8]. The local sheep are sheep breeds raised by local people in particular area and proven to be adaptable in that area [9]. At present, eight local Indonesian sheep breeds have been established by the Ministry of Agriculture of the Republic of Indonesia, four of which were developed in the original area on Java Island, namely, Garut (GRT), Batur (BTR), Wonosobo (WSB), and Priangan (PRG) sheep. Each breed has phenotypic characteristics that are easily recognized, but genetically many things have not been studied. Local Indonesian sheep that are developing at this time might be the result of a cross between thintailed sheep or fat-tailed sheep $[10,11]$. These sheep 
types have already been developed by the community with other various breeds that were imported from abroad to form new sheep breeds in the development area. However, the genetic origin of local sheep is still not known with certainty.

One method to determine genetic diversity, relationships and origins of local Indonesian sheep are to examine the mitochondrial DNA (mtDNA) profile. The mtDNA is an important genetic study tool in population and systematic molecular genetics because it has many copies with a rapid evolutionary rate and is inherited [12]. One part of mtDNA that can be observed is the displacement loop (D-loop) region or control region. The D-loop is a segment of mtDNA that acts as the initial intermediary for replication and is more variable than are other mtDNA regions [3]. Since the D-loop exhibits extraordinary levels of variation within species, it can be used to track geographical patterns of diversity and evolution (phylogeographic), distribution, gene flow, maternal origin, demographic expansion, genetic drift, population structures, and hybridization [13-15]. The use of the mtDNA D-loop sequence to determine the origin of sheep has been conducted in several wild sheep and domesticated sheep from Asia, Europe, and New Zealand [16,17]. However, no in-depth study of the genetic profile and origin of all local sheep breeds on Java Island according to breed have ever been determined based on the complete D-loop sequence.

This study aimed to determine the complete mtDNA D-loop sequences of six local sheep breeds on Java Island, Indonesia. The results of this study can be used to determine genetic diversity, genetic distance, and relationships between local sheep breeds and other species of sheep on Java Island. Furthermore, the results can be added to databases and used to complement previous studies on genetic diversity and relationships of local Indonesian sheep, especially on Java Island.

\section{Materials and Methods}

\section{Ethical approval}

This study was approved by the Animal Care and Use Committee of the Faculty of Veterinary Medicine, Universitas Gadjah Mada, with the ethical clearance number 002/EC-FKH/Int/2019, and the National Political and Unity of Yogyakarta Special District with the approval number 074/1850/Kesbangpol/2019.

\section{Sample collection}

This study was conducted using blood samples from 22 individual sheep in six populations of local sheep breeds on Java Island and is presented in Figure-1. Sheep were sampled by a purposive sampling method, namely, by determining the local district sheep population center in the regency, and then the specified districts and villages. This study was conducted from April 2019 to February 2020. Blood was drawn using a $3 \mathrm{~mL}$ syringe through the jugular vein that had been previously cleaned with alcohol.
The blood was then collected in vacutainer tubes with anticoagulant (ethylenediaminetetraacetic acid), and then was stored in a cooler box containing an ice pack and transported to the laboratory for further analysis.

\section{Molecular techniques}

The DNA was extracted based on the manufacturer's standard protocol using PureLink ${ }^{\mathrm{TM}}$ Genomic DNA Mini Kits (Invitrogen, USA). The mtDNA D-loop was amplified directly from the genomic DNA by polymerase chain reaction (PCR). The primer was designed using the Primer3 online version 4.1.0 program (http://primer3.UT.ee//) [18] based on the data from the mitochondria genome of Ovis aries (GenBank accession number: AF010406.1). The mtDNA D-loop region primer sequences were Alek-DLF: 5'-GAAGAAGCTATAGCCCCACT-3' and Alek-DLR: 5'-GATTCGAAGGGCGTTACT-3' that generated $1397 \mathrm{bp}$ of the PCR product. The PCR reaction consisted of $4 \mu \mathrm{L}$ of DNA template, $25 \mu \mathrm{L}$ of KAPA2G Fast Ready Mix+Dye (Kapa Biosystems Ltd.), $2 \mu \mathrm{L}$ of forward primer, $2 \mu \mathrm{L}$ of reverse primer, and 17 of $\mathrm{ddH}_{2} \mathrm{O}$. The PCR amplification was conducted using Cleaver GTC96S (Cleaver Scientific Ltd.) according to the program: 6-min of pre-denaturation at $94^{\circ} \mathrm{C}$, followed by 35 cycles, each consisting denaturation at $94^{\circ} \mathrm{C}$ for $30-\mathrm{s}$, primers annealing at $47^{\circ} \mathrm{C}$ for 40 -s, extension at $72^{\circ} \mathrm{C}$ for 90 -s, then ending with a final extension at $72^{\circ} \mathrm{C}$ for 5 -min, and storage at $4^{\circ} \mathrm{C}$. The PCR product was visualized using $1.5 \%$ agarose gel, and electrophoresis was run at $100 \mathrm{mV}$ for 30-min. The result of amplification could be seen on the UV illuminator. The purified PCR products were sequenced by $1^{\text {st }}$ BASE-Asia, Malaysia.

\section{Statistical analysis}

The product length of the D-loop region sequences amplification for each individual is $1800 \mathrm{bp}$ and was analyzed using the molecular evolutionary genetics analysis (MEGA) version 7.0 software (Pennsylvania State University, USA) [19]. The D-loop region sequences of local sheep were aligned using the Clustal W program [20]. The analysis of genetic profiles was determined by the difference in the nucleotide sequence of the D-loop region. Genetic distance was analyzed using the Kimura 2-parameter method [21]. Genetic diversity and haplotype diversity (HD) were analyzed using DNA Sequence Polymorphism version 6 software (Universitat de Barcelona, Spain) [22].

Reference mtDNA D-loop region sequences of wild and domestic sheep of known haplogroup (Hap) types [23] were downloaded from GenBank and used as comparators of local sheep breeds on Java Island to look up phylogenetic trees and assume their origin (Table-1). The phylogenetic tree was constructed based on the D-loop region sequences using the neighbor-joining method [24] with bootstrap test 1000× replication [25] and Kimura 2-parameter method [21] in the MEGA program [19]. 


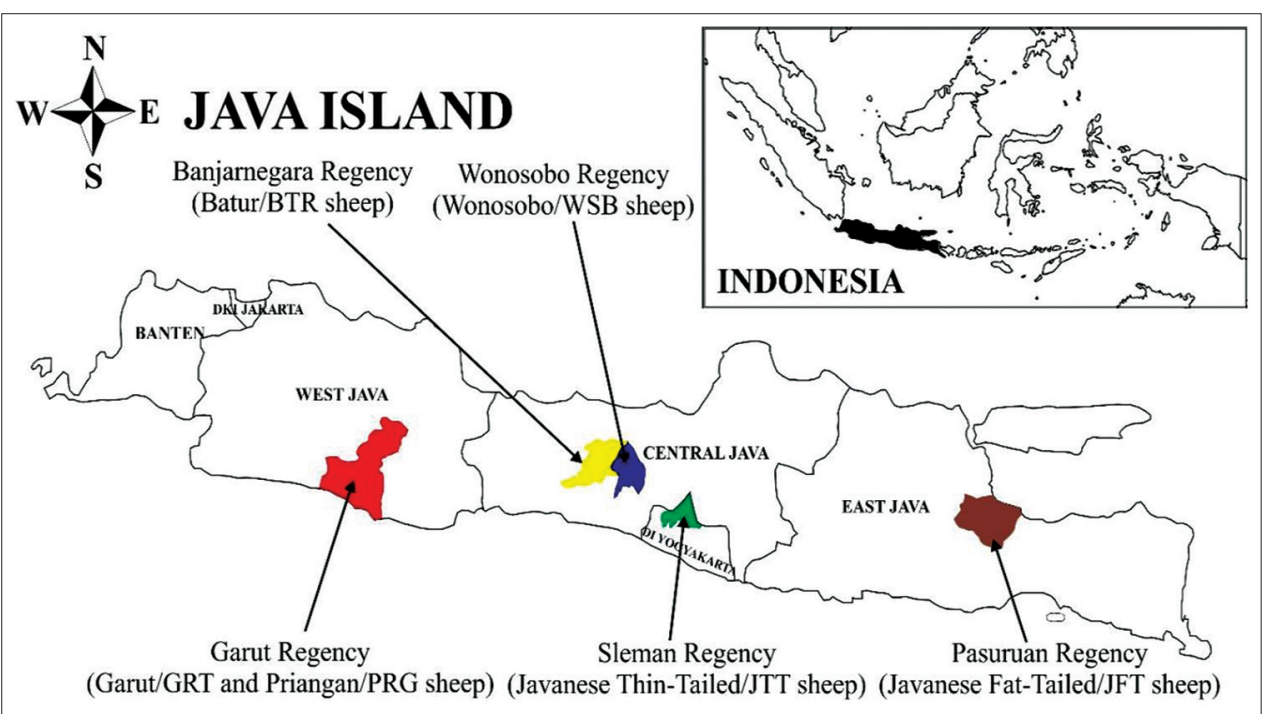

Figure-1: Sampling sites local sheep on Java Island, Indonesia.

Table-1: References of domestic and wild sheep.

\begin{tabular}{lc}
\hline Group membership & GenBank accession number \\
\hline Ovis aries & \\
Haplogroup A & $\mathrm{HM} 236174, \mathrm{HM} 236175$ \\
Haplogroup B & $\mathrm{H} 236176, \mathrm{HM} 236177$ \\
Haplogroup C & $\mathrm{H} 236178, \mathrm{HM} 236179$ \\
Haplogroup D & $\mathrm{H} 236180, \mathrm{HM} 236181$ \\
Haplogroup E & $\mathrm{HM} 236182, \mathrm{HM} 236183$ \\
Ovis musimon & $\mathrm{HM} 236184$ \\
Ovis vignei & $\mathrm{HM} 236187$ \\
Ovis ammon & $\mathrm{HM} 236188$ \\
Ovis orientalis & $\mathrm{KF} 312238$ \\
Ovis canadensis & $\mathrm{MH} 094035$ \\
Ovis nivicola & $\mathrm{MH} 779626$ \\
Ovis dalli & $\mathrm{MH} 779627$ \\
\hline
\end{tabular}

\section{Results}

\section{Genetic diversity and HD}

All local sheep breeds on Java Island have D-loop sequences of $1180 \mathrm{bp}$ except for one sample (GRT2) that has a length of $1181 \mathrm{bp}$. The length of this sequence, as the long sequence of the D-loop on Ovis aries (AF010406.1), was equal to $1180 \mathrm{bp}$. However, differences were found in the sequence at 908 where $\mathrm{C}$ nucleotide insertion and deletion in the sequence at 1037 except in the GRT2 sample, which still has a T nucleotide at the site.

The alignment of mtDNA D-loop nucleotide sequences of local sheep breeds on Java Island enabled polymorphic site data to be obtained and is presented in Figure-2. The average percentage of $\mathrm{T}, \mathrm{A}, \mathrm{C}$, and $\mathrm{G}$ nucleotides were $29.5 \%, 31.1 \%, 22.9 \%$, and $14.4 \%$, respectively. The percentage of $\mathrm{A}+\mathrm{T}$ and $\mathrm{C}+\mathrm{G}$ nucleotide pairs was $62.6 \%$ and $37.4 \%$, respectively. Based on the aligned D-loop mtDNA nucleotide sequence (Figure-2), specific nucleotide substitutions were obtained that might represent the genetic markers in each breed. The Javanese thin-tailed (JTT) has four unique polymorphic sites, namely, at sites 272,422 , 606 , and 660 . The unique polymorphic has not been found in the other breed that can distinguish it from other breeds.

The parameters of genetic diversity and HD of the mtDNA D-loop region in six subpopulations of local sheep breeds on Java Island are as shown in Table-2. The sequencing of the six local sheep breeds on Java Island generated sequences of the D-loop region throughout $1180 \mathrm{bp}$ and 1 indel (insertion or deletion) $(1180+1: 1181)$. It showed that there were 123 polymorphic sites (V) (Figure-2), which consisted of 63 parsimony informative sites $(\mathrm{P})$ and 60 singleton variable sites (S), and 130 of the total number of mutations. From 22 samples, there were 21 haplotypes (Hap) with 20 unique haplotypes and 1 shared haplotype (Hap6: JFT3 and BTR4). The average $\mathrm{HD}$, the average number of pairwise differences $(\mathrm{K})$, and nucleotide diversity $(\mathrm{Pi})$ of the complete mtDNA D-loop in six local sheep breeds of Java Island were $0.99567,25.36364$, and 0.02153 , respectively.

\section{Genetic distance}

The value of genetic distance within and between groups is presented in Table- 3 . The genetic distance value in local sheep groups on Java Island is 0.001 0.040 , with the lowest in JTT sheep and the highest in GRT sheep. The genetic distance values between groups of local sheep breeds range between 0.004 and 0.036. The lowest genetic distance is between Javanese fat-tailed (JFT) and BTR or WSB, whereas the highest is between JTT and PRG. The JFT, BTR, and WSB populations have a high genetic distance value with GRT and PRG.

\section{Phylogenetic relationship}

The phylogenetic tree of 21 haplotypes in six subpopulations of local sheep breeds on Java Island and mtDNA D-loop sequences of wild sheep and domestic sheep categorized by Hap from GenBank are presented in Figure-3. The phylogenetic analysis showed that local sheep breeds on Java Island are divided into 


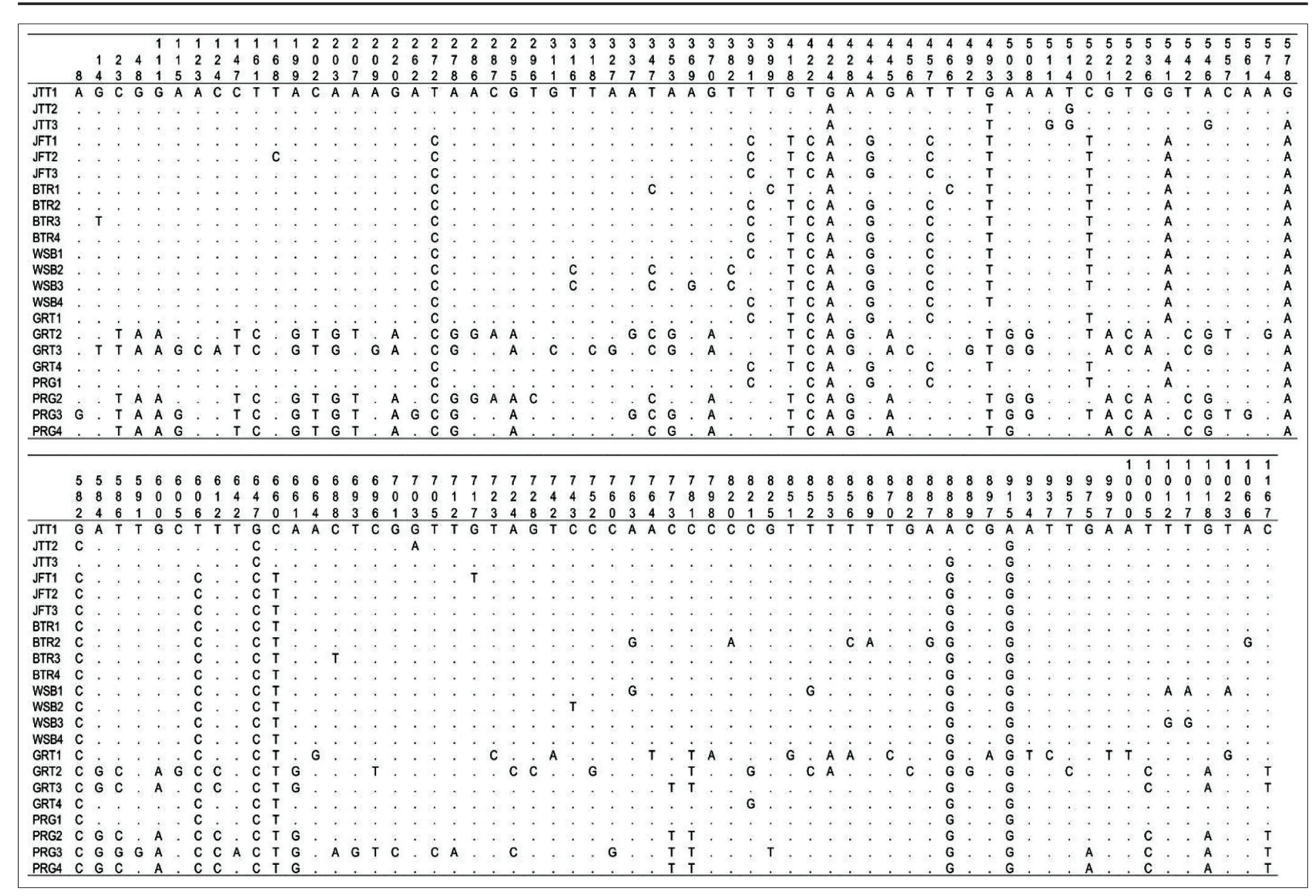

Figure-2: Polymorphic sites of mitochondrial DNA D-loop in the local sheep breeds on Java Island.

Table-2: Genetic diversity and haplotype diversity of local sheep breeds on Java Island based on complete mtDNA D-Loop sequence.

\begin{tabular}{|c|c|c|c|c|c|c|c|c|c|c|c|}
\hline Breeds & $\mathbf{n}$ & $\mathbf{v}$ & $\mathbf{S}$ & $\mathbf{P}$ & Indel & nHap & HapA & НарВ & HD & $\mathbf{K}$ & $\mathbf{P i}$ \\
\hline All & 22 & 123 & 60 & 63 & 1 & 21 & 5 & 16 & 0.99567 & 25.36364 & 0.02153 \\
\hline $\mathrm{JTT}$ & 3 & 11 & 11 & 0 & 0 & 3 & 0 & 3 & 1.00000 & 7.33333 & 0.00623 \\
\hline JFT & 3 & 2 & 2 & 0 & 0 & 3 & 0 & 3 & 1.00000 & 1.33333 & 0.00113 \\
\hline BTR & 4 & 15 & 15 & 0 & 0 & 4 & 0 & 4 & 1.00000 & 7.50000 & 0.00637 \\
\hline WSB & 4 & 12 & 8 & 4 & 0 & 4 & 0 & 4 & 1.00000 & 7.33333 & 0.00623 \\
\hline GRT & 4 & 80 & 43 & 37 & 1 & 4 & 2 & 2 & 1.00000 & 45.16667 & 0.03834 \\
\hline PRG & 4 & 62 & 57 & 5 & 0 & 4 & 3 & 1 & 1.00000 & 31.66667 & 0.02688 \\
\hline
\end{tabular}

JTT=Javanese thin-tailed sheep, JFT=Javanese fat-tailed sheep, BTR=Batur sheep, WSB=Wonosobo sheep, GRT=Garut sheep, $\mathrm{PRG}=$ Priangan sheep. $\mathrm{n}=$ Number of samples, $\mathrm{V}=$ Polymorphic sites, $\mathrm{S}=$ Singleton variable sites, $\mathrm{P}=\mathrm{Parsimony}$ informative sites, Indel=Insertion and deletion. $\mathrm{nHap}=$ Number of haplotypes, HapA=Haplogroup A, HapB=Haplogroup B, $\mathrm{HD}=$ Haplotype diversity, $\mathrm{K}=$ Average number of pairwise different, $\mathrm{Pi}=$ Nucleotide diversity

Table-3: Genetic distance values within and between groups of local sheep breeds on Java Island based on complete mtDNA D-Loop sequence.

\begin{tabular}{lcccccc}
\hline Population & JTT & JFT & BTR & WSB & GRT & PRG \\
\hline JTT & $\mathbf{0 . 0 0 6}$ & & & & & \\
JFT & 0.013 & $\mathbf{0 . 0 0 1}$ & & & & \\
BTR & 0.014 & 0.004 & $\mathbf{0 . 0 0 6}$ & & & \\
WSB & 0.015 & 0.004 & 0.007 & $\mathbf{0 . 0 0 6}$ & & \\
GRT & 0.034 & 0.026 & 0.028 & 0.029 & $\mathbf{0 . 0 4 0}$ & \\
PRG & 0.036 & 0.031 & 0.032 & 0.032 & 0.030 & $\mathbf{0 . 0 2 8}$
\end{tabular}

JTT=Javanese thin-tailed sheep, JFT=Javanese Fat-

Tailed sheep, BTR=Batur sheep, WSB=Wonosobo sheep, GRT=Garut sheep, PRG=Priangan sheep. Genetic distance values between groups are shown in normal and within groups are shown in bold

two Hap, namely, Hap A and B. All JTT, JFT, BTR, and WSB sheep are categorized into Hap B.

\section{Discussion}

Genetic diversity and genetic distance of local sheep breeds on Java Island, Indonesia

The sequence length, in this study, is the same as the length of the D-loop sequence in $O$. aries (AF010406.1), which is $1800 \mathrm{bp}$, but there is a difference at the 908 site where the $\mathrm{C}$ nucleotide is inserted. A deletion occurs at the 1037 site except for GTR2 samples (Figure-1), which has 1 indel (Table-2), but still has a $\mathrm{T}$ nucleotide on the site. The sequence length and characteristics of the $\mathrm{T}$ nucleotide at the 1037 site on GRT2 are similar to those of the Ovis orientalis (KF312238). The nucleotide composition of six local sheep on Java in this study was almost similar to Tibetan sheep [26,27], Small-Tailed Hulun Buir sheep, Shandong Large-Tailed sheep, Altay 


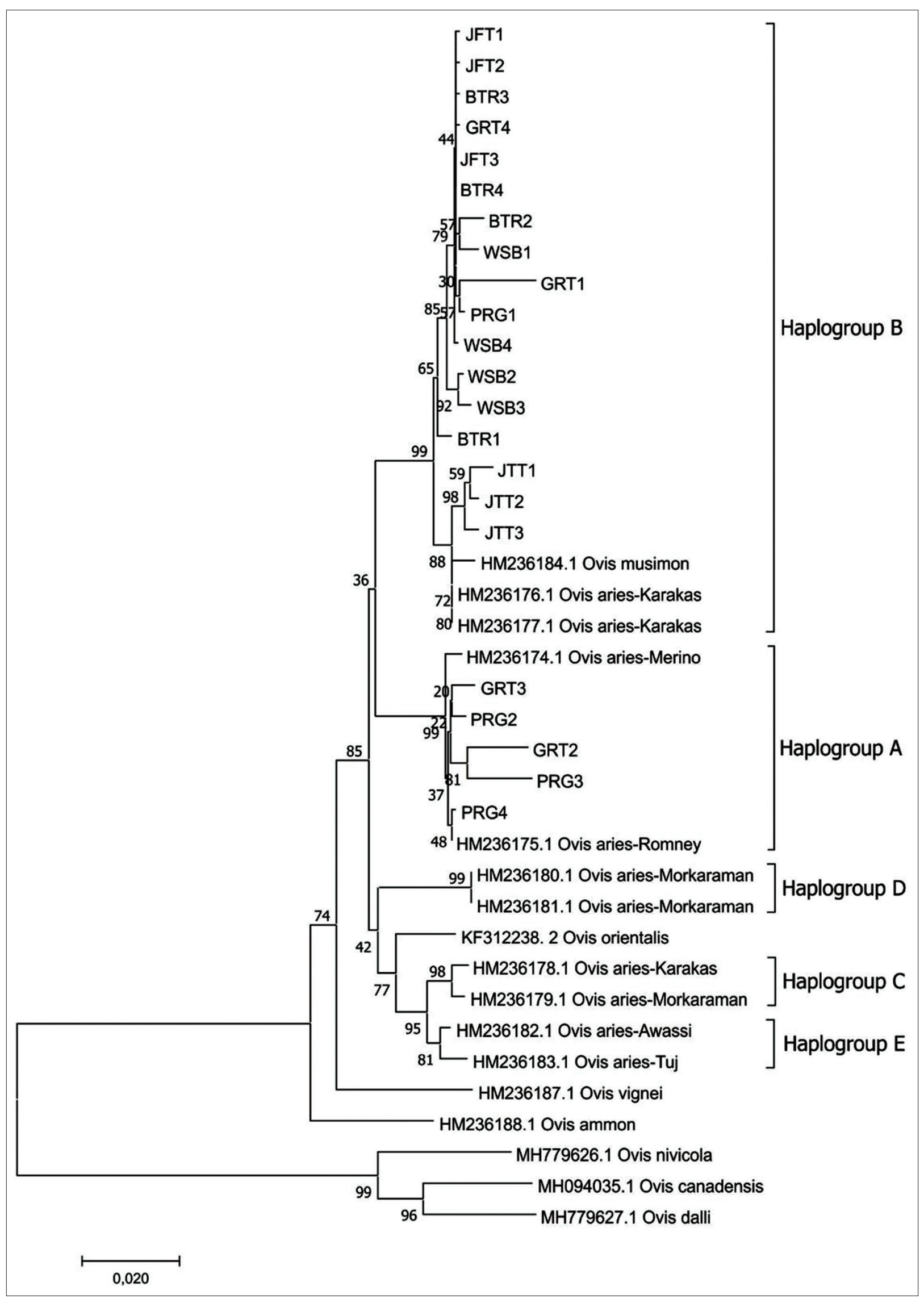

Figure-3: Phylogenetic tree of six local sheep breeds on Java Island compared with other species of sheep.

sheep [28], and Alpine Merino sheep [29], with the $A+T$ pairs were substantially more common than the $\mathrm{G}+\mathrm{C}$ pairs.
Genetic diversity, besides reflecting differences in traits between individuals, also reflects small differences in nucleotides [15]. Genetic diversity (Pi) 
values ranged from 0.001 to 0.01 and defined three categories, that is, a high category that ranged from 0.008 to 0.01 , a medium category that ranged from 0.005 to 0.007 , and a low category that ranged from 0.001 to 0.004 [30]. The analysis of mtDNA D-loop sequences in local sheep breeds on Java Island showed a high genetic diversity between breeds (0.02153) and within breeds (0.00623-0.03834), except for JFT (0.00113), which belonged to the medium category (Table-2). The values obtained in this study are similar to the genetic diversity within breeds of ten Iranian indigenous breeds (0.00871-0.04762) [31], lower than five Egyptian sheep breeds (0.01433-0.03654) [32], Karayaka sheep (0.028-0.044) [33], and higher than Dorper sheep (0.0011) [34]. Nucleotide and HD of mtDNA are two important indices for assessing population polymorphism and genetic differentiation; the higher the HD, the higher the genetic diversity will be, and vice versa. Since the HD and nucleotide diversity of mtDNA are high, the population polymorphism is also high [26,35]. The difference in the results might be due to the research methods, including the analysis methods, sample location, and the number of samples $[36,37]$. High genetic diversity in these results might be influenced by increased mutation rates in the mtDNA D-loop, the maternal effect of multiple wild ancestors, crossbreeding, and intercrossing in agricultural practices, the mixing of populations from different geographical locations, overlapping generations, natural selection, and genetic drift $[36,38,39]$.

Genetic distance is the estimate of the closeness of genetic relationships or phylogenetics between the population, according to the Nei [30]. Genetic distance is close or equal to 0 (null) and is a very close genetic relationship. However, if the values are one or more apart, a very distant genetic relationship exists. Genetic distance values within groups of local sheep breeds on Java Island were between 0.001 and 0.040 , where the value is low. This means that within the same breed, they have a close relationship. The genetic distance between groups of local sheep breeds on Java Island is around 0.004-0.036. The lowest genetic distance is between JFT and BTR or WSB (0.004), whereas the highest is between JTT and PRG (0.036). The JFT, BTR, and WSB populations have a low genetic distance value but are quite high with GRT and PRG. This means that there is a considerable genetic relationship between JFT, BTR, and WSB with GRT and PRG. These results differ from the research Prayitno et al. [38], who found by PCRRAPD that BTR was closer to GRT than to JTT and JFT. However, based on the values of genetic distance according to Nei [30], the values of genetic distances in this study are still included in the category of a close genetic relationship. Need more research to find out more detail genetic diversity and genetic distances within and between populations. Further research can be carried out by comparing samples from other regions in Indonesia and from neighboring countries [40]. Apart from studying part of mtDNA, more detailed studies can also be carried out such as microsatellite [41,42], complete mitochondrial genome [27,43], whole-genome DNA [44,45], and the other studies using the next-generation sequencing [46] and/or the other methods.

\section{Haplotype analysis}

An HD value in the range $\geq 0<0.5$ was included in the low category, whereas an HD value in the range $>0.5 \leq 1$ was included in the high category [26,35]. Based on the analysis results, as presented in Table2, the HD value of six local sheep breeds on Java Island in this study is included in the high category. The HD value and the average number of pairwise differences $(\mathrm{K})$ within all tested breeds were 0.99567 and 25.36364, respectively. The HD value in this study is almost the same as fat-rumped sheep in Ethiopia (0.99) [47], five Egyptian sheep breeds (0.968) [37], four Polish sheep breeds (0.9720) [39], Savak Akkaraman sheep (0.995) [48], Iranian indigenous sheep (0.996) [31], Karayaka sheep (0.998) [33], and Mongolian native sheep (0.93) [3]. The $\mathrm{K}$ value in this study is similar to 10 Iranian indigenous sheep breeds (25.23) [31], but higher than five Egyptian sheep breeds (17.14782) [37], Romanian Racka sheep (6.70488) [49], and Savak Akkaraman sheep (7.068) [48].

The results of analyzing 22 individual samples were used as the basis to form 21 unique haplotypes and one shared haplotype. A comparison of the number of individual samples and the number of haplotypes (Table-2) indicated that each breed had its haplotypes that could be due to the high diversity in local sheep breeds on Java Island and/or sampling strategy (collecting unrelated individuals) [31]. This is in line with the previous studies which states that several sheep breeds in Indonesia have high genetic diversity within [39] and between [50] populations. Unique patterns in the distribution of haplotypes could be attributed to the total reproductive isolation because of the harsh geographical structure of and unique husbandry practice on Java Island, that allow farmers to select animals with unique phenotypic characters associated with the adaptability to different ecological conditions [51,52].

\section{Phylogenetic relationship and the maternal origin of local sheep breeds on Java Island}

Domestic sheep were divided into five Hap, namely, A, B, C, D, and E [53]. Based on phylogenetic relationship analysis, this study shows that six local sheep breeds on Java Island are divided into two Hap, namely, Hap A and B (Figure-3 and Table-2). This is in line with the statement of Meadows et al. [53] that Indonesian sheep have two Hap, namely, Hap A and B. Hap A is mainly represented in Asian breeds, whereas Hap B is found in high frequencies in European breeds $[54,55]$. This study is similar to observations on four Polish sheep breeds [39], eastern Ethiopia sheep [47], and Kail sheep [56] that form two Hap, 
namely, Hap A and B. All JFT, JTT, BTR, and WSB sheep are classified as Hap B. Most GRT and PRG sheep are classified as Hap A, but there are GRT sheep (GRT1 and GRT2) and PRG1 sheep that are classified as Hap B. This pattern is similar to that observed for the five Egyptian sheep breeds [37], Romanian Racha Sheep [49], and Iberian sheep [57] where Hap B is predominant over Hap A. However, this in contrast to the observations of the four Nepal indigenous sheep breeds [51], Tibetan sheep [26], and native Mongolian sheep [3], where Hap A is predominant over Hap B.

This study indicates that most local sheep breeds on Java Island are descendants of European type sheep. This is also supported by the phylogenetic analysis that showed a close relationship with Ovis musimon (European Mouflon) (Figure-3). In contrast, Dudu et al. [49] stated that different breeds from Asia (Indonesia, India, and Mongolia) presented exclusively type A haplotypes. The JTT sheep in this study were all classified as Hap B. However, the study of Meadows et al. [53] found that the JTT sheep are divided into two Hap, namely, Hap A and B. The existence of two divisions of the two Hap is found in GRT and PRG sheep. The GRT and PRG sheep are mostly classified into Hap A, are different from other sheep breeds classified into Hap B. It could be because it is still an Asian breed (Asian Mouflon), or it can also be related to the Merino breed. Another possibility is that the GRT and PRG sheep were previously categorized as local subpopulations or strains of JTT [10]. In contrast, the two breeds were only designated as local Indonesian sheep breeds in 2011 [58] and 2017 [59]. The designation of local sheep breeds by the Ministry of Agriculture of the Republic of Indonesia and the results of this study can be the basis for future research related to the specific determination of samples of sheep breeds used. There is a need for further studies with more samples to determine the type of Hap in more detail.

According to the Ministry of Agriculture [59], the origin of the PRG sheep began in 1864 by the Dutch government who imported Merino sheep into the PRG Residency, West Java. PRG sheep are a cross between local sheep, Texel, and Merino [6]. GRT sheep are the result of crossing Merino sheep from Australia, Kaapstad sheep from Africa, and JFT sheep [60]. The phylogenetic analysis (Figure-2) shows the closeness of the PRG sheep and GRT sheep with Merino sheep from Australia (HM236174). Previous research stated that sheep from Indonesia, Mongolia, and Tibet had a close Hap A sequence $[53,61]$. Observations in European Mouflon have found Hap B that predominates in European breeds and minorities in Eastern Asia breeds $[17,55,62,63]$. However, notable exceptions are the Indonesian breeds, which may have resulted from crossbreeding with breeds of European origin $[53,63]$.

Indonesia is an archipelago country between two continents (Asia and Australia) and two oceans
(Indian and Pacific). In the past, this area was named Nusantara, an area with many tribes and kingdoms that were a strategic region for trade with a variety of natural resources, especially spices. Many traders from Asia, including China and Gujarat (India), and from Europe, including Britain, Portugal, and the Netherlands/Dutch, traded in this region. Java Island is one of the islands in the Nusantara (Indonesia) that is a strategic destination of various regions for exploring and trading $[64,65]$. This vantage point enables the introduction of livestock from various countries into Indonesia for development before this country became independent in 1945. It had been occupied by the Dutch government for more than 300 years [65]. The Dutch government, at this time, often brought various livestock from outside the area to be raised in this area, such as cattle, goats, pigs, horses, and sheep [60]. No study has stated that native sheep or wild sheep originated from the original geographical area of Indonesia. It is possible that the sheep developed in Indonesia currently are from sheep breeds that were introduced and developed either by the traders' community or introduced by the Dutch government at the time.

This study shows that most local sheep breeds on Java Island are included in Hap B, which are sheep that have a close relationship with European sheep, even though this country is on the Asian continent. However, there are also local sheep breeds on Java Island that are included in Hap A. This indicates that the sheep that developed on Java Island were the result of crossing Asian and European sheep. However, this study is still limited to a small number of samples, but it can be used as a database for further research. Observations with data from mtDNA are used to determine the maternal inheritance line. It is necessary to have additional observations of the male's line so that both maternal and paternal lines can be known to find out more about the origin of developing breeds. In Indonesia, aside from Java Island, there are still other local sheep breeds that have been established by the Ministry of Agriculture, whereas others have not despite their long development in the region. Thus, further research on these breeds still needs to be done. In-depth studies need to be performed on the genetic profiles of local Indonesian sheep breeds with more samples, a wider area, more comparative data, and various other methods that can describe in more detail the origins, characteristics, and productivity of Indonesian sheep breeds.

\section{Conclusion}

The high genetic diversity of six local sheep breeds on Java Island suggests that they originated from different genetic resources. The JTT sheep have a closer genetic relationship to the JFT, BTR, and WSB sheep, and they are close to European sheep. In contrast, the GRT sheep have a closer genetic relationship 
to the PRG sheep. Both are closer to Asian sheep than they are to European sheep.

\section{Authors' Contributions}

WTA supervised the present study, and IGSB and RW designed and coordinated the study. AI performed the experiment, analyzed the data, and wrote the manuscript. The final manuscript has been read and developed in consultation with all authors. All authors read and approved the final manuscript.

\section{Acknowledgments}

The authors are thankful to the Director General of Higher Education, Ministry of Education and Culture of the Republic of Indonesia, for funding this study with the Pendidikan Magister menuju Doktor untuk Sarjana Unggul program (Grant No. 27/E1/ KPT/2020 with contract no. 3175/UN1.DITLIT/ DIT-LIT/PT/2020). The authors also thank PT. Agro Investama and Universitas Gadjah Mada, Indonesia, for the support and thank all respondents.

\section{Competing Interests} interests.

The authors declare that they have no competing

\section{Publisher's Note}

Veterinary World remains neutral with regard to jurisdictional claims in published map and institutional affiliation.

\section{References}

1. Budisatria, I.G.S., Panjono, P., Maharani, D. and Ibrahim, A. (2018) Kambing Peranakan Etawah: Kepala Hitam atau Cokelat? Gadjah Mada University Press, Yogyakarta.

2. Ibrahim, A., Budisatria, I.G.S., Widayanti, R. and Artama, W.T. (2019) The impact of religious festival on roadside livestock traders in urban and peri-urban areas of Yogyakarta, Indonesia. Vet. World, 12(9): 1408-1415.

3. Ganbold, O., Lee, S.H., Seo, D., Paek, W.K. and Manjula, P. (2019) Genetic diversity and the origin of Mongolian native sheep. Livest. Sci., 220: 17-25.

4. Cai, D., Zhang, N., Shao, X., Sun, W., Zhu, S. and Yang, D.Y. (2018) New ancient DNA data on the origins and spread of sheep and cattle in Northern China around 4000 BP. Asian Archaeol., 2(1): 51-57.

5. Budisatria, I.G.S., Yulianto, M.D.E., Ibrahim, A., Atmoko, B.A. and Faqar, D. (2019) Profil Pedagang Ruminansia Kecil pada Periode Idul Adha di Daerah Istimewa Yogyakarta, Indonesia. Seminar Nasional Peternakan Tropis Berkelanjutan 3, Surakarta. p100-104.

6. Tawaf, R., Heriyadi, D., Anang, A., Sulaeman, M. and Hidayat, R. (2011) Empowerment of Small Holder Farmers Business Garut Sheep in West Java. International Conference on Sustainable Agricultural and Food Security: Challenges and Opportunities, London, United Kingdom. p1-8.

7. Ibrahim, A., Artama, W.T., Widayanti, R., Yulianto, M.D.E., Faqar, D. and Budisatria, I.G.S. (2019) Sheep traders preferences on marketing place and their satisfaction during Eid Al-Adha period in Yogyakarta, Indonesia. IOP Conf. Ser. Earth Environ. Sci., 372(1): 012071.

8. Ibrahim, A., Budisatria, I.G.S., Widayanti, R. and Artama, W.T. (2019) Consumer's preferences for sheep attributes for Eid Al-Adha celebration in Yogyakarta, Indonesia. IOP Conf. Ser. Earth Environ. Sci., 387(1): 012001 .
9. Ministry of Agriculture. (2011) Peraturan Menteri Pertanian Nomor 48/Permentan/OT.140/9/2011 Tentang Pewilayahan Sumber Bibit. Ministry of Agriculture of the Republic of Indonesia, Jakarta, Indonesia.

10. Sodiq, A. and Tawfik, E.S. (2004) Productivity and breeding strategies of sheep in Indonesia: A review. J. Agric. Rural Dev. Trop. Subtrop., 105(1): 71-82.

11. Ibrahim, A., Budisatria, I.G.S., Widayanti, R., Atmoko, B.A., Yuniawan, R. and Artama, W.T. (2020) On-farm body measurements and evaluation of batur sheep on different age and sex in Banjarnegara regency, Indonesia. Adv. Anim. Vet. Sci., 8(10): 1028-1033.

12. Wang, X., Ma, Y.H., Chen, H. and Guan, W.J. (2007) Genetic and phylogenetic studies of Chinese native sheep breeds (Ovis aries) based on mtDNA D-loop sequences. Small Rumin. Res., 72: 232-236.

13. Bruford, M.W., Bradley, D.G. and Luikart, G. (2003) DNA markers reveal the complexity of livestock domestication. Nat. Rev. Genet., 4(11): 900-910.

14. Ganbold, O., Lee, S.H., Paek, W.K., Munkhbayar, M., Seo, D., Manjula, P., Khujuu, T., Purevee, E. and Lee, J.H. (2020) Mitochondrial DNA variation and phylogeography of native Mongolian goats. Asian Aust. J. Anim. Sci., 33(6): 902-912.

15. Ju, Y., Liu, H., He, J., Wang, L., Xu, J., Liu, H. and Dong, Y. (2020) Genetic diversity of Aoluguya reindeer based on D-loop region of mtDNA and its conservation implications. Gene, 733: 144271.

16. Hiendleder, S., Lewalski, H., Wassmuth, R. and Janke, A. (1998) The complete mitochondrial DNA sequence of the domestic sheep (Ovis aries) and comparison with the other major ovine haplotype. J. Mol. Evol., 47(4): 441-448.

17. Hiendleder, S., Kaupe, B., Wassmuth, R. and Janke, A. (2002) Molecular analysis of wild and domestic sheep questions current nomenclature and provides evidence for domestication from two different subspecies. Proc. R. Soc. B Biol. Sci., 269(1494): 893-904.

18. Kõressaar, T., Lepamets, M., Kaplinski, L., Raime, K., Andreson, R. and Remm, M. (2018) Primer3-masker: Integrating masking of template sequence with primer design software. Bioinformatics, 34(11): 1937-1938.

19. Kumar, S., Stecher, G. and Tamura, K. (2016) MEGA7: Molecular evolutionary genetics analysis version 7.0 for bigger datasets. Mol. Biol. Evol., 33(7): 1870-1874.

20. Thompson, J.D., Higgins, D.G. and Gibson, T.J. (1994) CLUSTAL W: Improving the sensitivity of progressive multiple sequence alignment through sequence weighting, position-specific gap penalties and weight matrix choice. Nucleic Acids Res., 22(22): 4673-4680.

21. Kimura, M. (1980) A simple method for estimating evolutionary rates of base substitutions through comparative studies of nucleotide sequences. J. Mol. Evol., 16(2): 111-120.

22. Rozas, J., Ferrer-Mata, A., Sanchez-DelBarrio, J.C., Guirao-Rico, S., Librado, P., Ramos-Onsins, S.E. and Sanchez-Gracia, A. (2017) DnaSP v6: DNA sequence polymorphism analysis of large datasets. Mol. Biol. Evol., 34(12): 3299-3302.

23. Meadows, J.R.S., Hiendleder, S. and Kijas, J.W. (2011) Haplogroup relationships between domestic and wild sheep resolved using a mitogenome panel. Heredity (Edinb), 106(4): 700-706.

24. Saitou, N. and Nei, M. (1987) The Neighbor-joining method: A new method for reconstructing phylogenetic trees. Mol. Biol. Evol., 4(4): 406-425.

25. Felsenstein, J. (1985) Confidence limits on phylogenies: An approach using the bootstrap. Evolution (N.Y), 39(4): 783-791.

26. Liu, J., Ding, X., Zeng, Y., Yue, Y., Guo, X., Guo, T., Chu, M., Wang, F., Han, J., Feng, R., Sun, X., Niu, C., Yang, B., Guo, J. and Yuan, C. (2016) Genetic diversity and phylogenetic evolution of Tibetan sheep based on mtDNA D-loop sequences. PLoS One, 11(7): e0159308. 
27. Liu, J.B., Ding, X.Z., Guo, T.T., Yue, Y.J., Zeng, Y.F., Guo, X., Chu, M., Han, J.L., Sun, X.P., Niu, C.E., Yang, B.H., Guo, J. and Yuan, C. (2016) The complete mitochondrial genome sequence of the wild Huoba Tibetan sheep of the Qinghai-Tibetan Plateau in China. Mitochondrial DNA Part A, 27(6): 4689-4690.

28. Fan, H., Zhao, F., Zhu, C., Li, F., Liu, J., Zhang, L., Wei, C. and $\mathrm{Du}, \mathrm{L}$. (2016) Complete mitochondrial genome sequences of Chinese indigenous sheep with different tail types and an analysis of phylogenetic evolution in domestic sheep. Asian Aust. J. Anim. Sci., 29(5): 631-639.

29. Qiao, G., Zhang, H., Zhu, S., Yuan, C., Zhao, H., Han, M., Yue, Y. and Yang, B. (2020) The complete mitochondrial genome sequence and phylogenetic analysis of Alpine Merino sheep (Ovis aries). Mitochondrial DNA Part B, 5(1): 990-991.

30. Nei, M. (1987) Molecular Evolutionary Genetics. Columbia University Press, New York.

31. Rafia, P. and Tarang, A. (2016) Sequence variations of mitochondrial DNA displacement-loop in Iranian Indigenous sheep breeds. Iran. J. Appl. Anim. Sci., 6(2): 363-368.

32. Othman, O.E.M., Payet-Duprat, N., Harkat, S., Laoun, A., Maftah, A., Lafri, M. and Da Silva, A. (2016) Sheep diversity of five Egyptian breeds: Genetic proximity revealed between desert breeds: Local sheep breeds diversity in Egypt. Small Rumin. Res., 144(10): 346-352.

33. Kirikci, K., Noce, A., Akif, M., Mercan, L., Amills, M., Cam, M.A., Mercan, L. and Amills, M. (2018) The analysis of mitochondrial data indicates the existence of population substructure in Karayaka sheep. Small Rumin. Res., 162: 25-29.

34. de Oliveira, J.A., do Egito, A.A., do Amaral Crispim, B., de Vargas Junior, F.M., de Oliveira Seno, L. and Barufatti, A. (2020) Importance of naturalized breeds as a base for the formation of exotic sheep (Ovis aries) breeds in tropical altitude regions. Genet. Mol. Biol., 43(2): e20190054.

35. Zhao, Y., Zhao, E., Zhang, N. and Duan, C. (2011) Mitochondrial DNA diversity, origin, and phylogenic relationships of three Chinese large-fat-tailed sheep breeds. Trop. Anim. Health Prod., 43(7): 1405-1410.

36. Selvam, R., Murali, N., Thiruvenkadan, A.K., Saravanakumar, R., Ponnudurai, G. and Jawahar, T.P. (2017) Single-nucleotide polymorphism-based genetic diversity analysis of the Kilakarsal and Vembur sheep breeds. Vet. World, 10(5): 549-555.

37. Othman, O.E., Balabel, E.A. and Abdel-Samad, M.F (2014) Mitochondrial DNA diversity in five Egyptian sheep breeds. Glob. Vet., 12(3): 369-375.

38. Prayitno, P., Hartatik, T., Pratiwi, R. and Artama, W.T (2008) Genetic relatedness between Batur, Merino and local sheep based on random amplified polymorphism DNA marker. Anim. Prod., 13(1): 30-38.

39. Koseniuk, A. and Słota, E. (2016) Mitochondrial control region diversity in Polish sheep breeds. Arch. Anim. Breed., 59(2): 227-233.

40. Kim, Y.S., Tseveen, K., Batsukh, B., Seong, J. and Kong, H.S. (2020) Origin-related study of genetic diversity and heteroplasmy of Mongolian sheep (Ovis aries) using mitochondrial DNA. J. Anim. Reprod. Biotechnol., 35(2): 198-206.

41. Amareswari, P., Gnana Prakash, M., Ekambaram, B., Mahendar, M. and Krishna, C.H. (2018) Molecular genetic studies on Nellore and Deccani sheep using microsatellite markers. Indian J. Anim. Res., 52(6): 805-810.

42. Abdelkader, A.A., Ata, N., Benyoucef, M.T., Djaout, A., Azzi, N., Yilmaz, O., Cemal, İ. and Gaouar, S.B.S. (2018) New genetic identification and characterisation of 12 Algerian sheep breeds by microsatellite markers. Ital. $J$. Anim. Sci., 17(1): 38-48.

43. Wang, C., Xu, H., Li, D., Wu, J., Wen, A., Xie, M., Wang, Q., Zhu, G., Ni, Q., Zhang, M. and Yao, Y. (2020) Phylogenetic and characterization of the complete mitochondrial genome relationship of Argali sheep (Ovis ammon). Mitochondrial DNA Part B Resour., 5(1): 273-274.

44. Heaton, M.P., Smith, T.P.L., Freking, B.A., Workman, A.M., Bennett, G.L., Carnahan, J.K. and Kalbfleisch, T.S. (2017) Using sheep genomes from diverse U.S. Breeds to identify missense variants in genes affecting fecundity. F1000Research, $6: 1303$.

45. Deniskova, T.E., Dotsev, A.V., Selionova, M.I., Kunz, E., Medugorac, I., Reyer, H., Wimmers, K., Barbato, M., Traspov, A.A., Brem, G. and Zinovieva, N.A. (2018) Population structure and genetic diversity of 25 Russian sheep breeds based on whole-genome genotyping. Genet. Sel. Evol., 50(1): 1-16.

46. Dunisławska, A., Łachmańska, J., Sławińska, A. and Siwek, M. (2017) Next generation sequencing in animal science-a review. Anim. Sci. Pap. Reports, 35(3): 205-224.

47. Nigussie, H., Mwacharo, J.M., Osama, S., Agaba, M., Mekasha, Y., Kebede, K., Abegaz, S. and Pal, S.K. (2019) Genetic diversity and matrilineal genetic origin of fatrumped sheep in Ethiopia. Trop. Anim. Health Prod., 51(6): 1393-1404.

48. Yağci, S., Baş, S. and Kiraz, S. (2020) Study of mitochondrial DNA (mtDNA) D-loop region polymorphism in Şavak Akkaraman sheep. Turk. J. Vet. Anim. Sci., 44(2): 323-330.

49. Dudu, A., Ghita, E., Costache, M. and Georgescu, S.E. (2016) Origin and genetic diversity of Romanian Racka sheep using mitochondrial markers. Small Rumin. Res., 144: $276-282$.

50. Jakaria, J., Zein, M.S.A., Sulandari, S., Subandriyo, S. and Muladno, M. (2012) The use of microsatellite markers to study genetic diversity in Indonesia sheep. J. Indones. Trop. Anim. Agric., 37(1): 1-9.

51. Gorkhali, N.A., Han, J.L. and Ma, Y.H. (2015) Mitochondrial DNA variation in indigenous sheep (Ovis aries) breeds of Nepal. Trop. Agric. Res., 26(4): 632-641.

52. Yang, J., Li, W.R., Lv, F.H., He, S.G., Tian, S.L., Peng, W.F., Sun, Y.W., Zhao, Y.X., Tu, X.L., Zhang, M., Xie, X.L., Wang, Y.T., Li, J.Q., Liu, Y.G., Shen, Z.Q., Wang, F., Liu, G.J., Lu, H.F., Kantanen, J., Han, J.L., Li, M.H. and Liu, M.J. (2016) Whole-genome sequencing of native sheep provides insights into rapid adaptations to extreme environments. Mol. Biol. Evol., 33(10): 2576-2592.

53. Meadows, J.R.S., Li, K., Kantanen, J., Tapio, M., Sipos, W., Pardeshi, V., Gupta, V., Calvo, J.H., Whan, V., Norris, B. and Kijas, J.W. (2005) Mitochondrial sequence reveals high levels of gene flow between breeds of domestic sheep from Asia and Europe. J. Hered., 96(5): 494-501.

54. Hiendleder, S., Mainz, K., Plante, Y. and Lewalski, H. (1998) Analysis of mitochondrial DNA indicates that domestic sheep are derived from two different ancestral maternal sources: No evidence for contributions from urial and argali sheep. J. Hered., 89(2): 113-20.

55. Mereu, P., Pirastru, M., Barbato, M., Satta, V., Hadjisterkotis, E., Manca, L., Naitana, S. and Leoni, G.G. (2019) Identification of an ancestral haplotype in the mitochondrial phylogeny of the ovine haplogroup B. PeerJ, 7: e7895.

56. Hussain, T., Babar, M.E. and Wajid, A. (2016) Extra nuclear DNA control region and cytochrome $b$ gene based phylogeny of kail sheep breed of Azad Jammu and Kashmir: Implications towards conservation. J. Anim. Plant Sci., 26(6): 1890-1893.

57. Pedrosa, S., Arranz, J.J., Brito, N., Renseigné, N., San Primitivo, F. and Bayón, Y. (2007) Mitochondrial diversity and the origin of Iberian sheep. Genet. Sel. Evol., 39(1): 91-103.

58. Ministry of Agriculture. (2011) Keputusan Menteri Pertanian Nomor 2914/Kpts/OT.140/6/2011 Tentang Penetapan Rumpun Domba Garut. Ministry of Agriculture of the Republic of Indonesia, Jakarta, Indonesia.

59. Ministry of Agriculture. (2017) Keputusan Menteri Pertanian Republik Indonesia Nomor 300/Kpts/SR.120/5/2017 
Tentang Penetapan Rumpun Domba Priangan. Ministry of Agriculture of the Republic of Indonesia, Jakarta, Indonesia.

60. Directorate General of Livestock Services. (2003) National Report on Animal Genetic Resources Indonesia, A Strategic Policy Document. Ministry of Agriculture of the Republic of Indonesia, Jakarta.

61. Guangxin, E., Yong-Ju, Z., Ri-Su, N., Yue-Hui, M., JiaHua, Z., Li-Peng, C., Xiao-Yu, Q., Zhong-Quan, Z., Ya-Wang, S., Xin, W. and Yong-Fu, H. (2017) Metaanalysis evidence of maternal lineages in Chinese Tibetan sheep using mtDNA D-loop panel. Mitochondrial DNA A DNA Mapp. Seq. Anal., 28(4): 579-583.

62. Guo, J., Du, L.X.L., Ma, Y.H., Guan, W.J., Li, H.B.,
Zhao, Q.J., Li, X., Rao, A.Q. and Rao, S.Q. (2005) A novel maternal lineage revealed in sheep (Ovis aries). Anim. Genet., 36(4): 331-336.

63. Tapio, M., Marzanov, N., Ozerov, M., Ćinkulov, M., Gonzarenko, G., Kiselyova, T., Murawski, M., Viinalass, H. and Kantanen, J. (2006) Sheep mitochondrial DNA variation in European, Caucasian, and Central Asian areas. Mol. Biol. Evol., 23(9): 1776-1783.

64. Ricklefs, M.C. (1981) A History of Modern Indonesia c. 1300 to the Present. The Macmillan Press Ltd., London.

65. Vickers, A. (2005) A History of Modern Indonesia. Cambridge University Press, London.

$* * * * * * * *$ 